\title{
Amalu (pl. imula, ubac)
}

S. Chaker

\section{OpenEdition}

Journals

Édition électronique

URL : http://journals.openedition.org/encyclopedieberbere/2459

DOI : 10.4000/encyclopedieberbere.2459

ISSN : 2262-7197

\section{Éditeur}

Peeters Publishers

\section{Édition imprimée}

Date de publication : 1 septembre 1986

Pagination : 555-556

ISBN : 2-85744-282-3

ISSN : 1015-7344

\section{Référence électronique}

S. Chaker, «Amalu (pl. imula, ubac) », Encyclopédie berbère [En ligne], 4 | 1986, document A177, mis en ligne le 01 décembre 2012, consulté le 13 octobre 2020. URL : http://journals.openedition.org/ encyclopedieberbere/2459; DOI : https://doi.org/10.4000/encyclopedieberbere.2459

Ce document a été généré automatiquement le 13 octobre 2020

(c) Tous droits réservés 


\section{Amalu (pl. imula, ubac)}

\section{S. Chaker}

1 Terme pan-berbère, largement attesté dans l'ensemble des dialectes berbères nord, tout particulièrement dans la toponymie et l'ethnonymie :

- Kabyle : amalu (pl. imula) : « ubac» (Dallet, p. 408);

- Maroc central : amalu (pl. imula) : « ombre » (Laoust, p. 292 et Mercier, 1937, p. 180) ;

- Chleuh : amalu (pl. imula) : «versant ombrageux » (Destaing, p. 292).

2 Le mot présente la forme d'un dérivé déverbatif (nom d'agent à préfixe $m$-) issu d'une racine ${ }^{*} L$ qui est certainement celle que l'on retrouve dans le lexème pan-berbère : tili, "ombre " (kabyle, Rif, Mzab, Ghadamès, touareg). Cette formation lui confère la signification première de: "ce qui est à l'ombre ", conservée en kabyle et en chleuh (« ubac, versant à l'ombre, versant nord»).

3 Dans son signifié de base, ce terme forme un couple oppositif avec asammer (kabyle et autres) ou anammer (chleuh), "versant exposé au soleil, adret », lui-même issu d'une racine *MR, "être exposé au soleil» (cf. touareg: émmar, "chaleur rayonnée...", Foucauld, III, pp. 1223-4).

4 Dans les régions montagneuses qui connaissent le binôme amalu/asammer, les deux termes jouent un rôle important dans l'organisation ethnico-géographique du territoire. Les groupes (tribus, confédérations...) étaient souvent divisés selon le paramètre amalu/asammer (ayt umalu / ayt usammer, « ceux du versant nord / ceux du versant sud».

5 Cette dichotomie est bien attestée en Kabylie (Ayt Iraten, Illulen...) où elle a souvent été reprise dans les découpages administratifs français et au Maroc. Chez les Imaziyen du Maroc central, la dénomination Ayt umalu couvrait un vaste ensemble de tribus centrées autour des Zayan (Išqern, Ayt Ihand, Ayt Ishaq, Ayt Ummel-bext, Ayt Wirra, Ayt Soxman).

6 Dans la néologie kabyle actuelle amalu/imula prend souvent - très naturellement - le sens technique de «nord». 


\section{BIBLIOGRAPHIE}

DALLET J.-M., Dictionnaire kabyle-français, Paris, SELAF, 1982.

FOUCAULD Ch. de, Dictionnaire touareg-français, Paris, 1951-52.

GUENNOUN S., La montagne berbère. Les Aït Oumalou et le pays Zayan 1933, L'Afrique française, 1929, 327 p. (notamment p. 40-41 et sq.).

LAOUST E., Cours de berbère marocain. Maroc central, Paris, 1928.

MERCIER G., Vocabulaire et textes berbères dans le dialecte des Aït Izdeg, Rabat, 1937.

INDEX

Mots-clés : Géographie, Linguistique, Maghreb 